\title{
Seroepidemiology of Leishmania infantum in dogs in the city of Porto Alegre, Rio Grande do Sul, Brazil
}

\author{
Soroepidemiologia de Leishmania infantum em cães de uma área \\ com ocorrência de casos no município de Porto Alegre, Rio Grande \\ do Sul
}

\author{
Mariana Caetano Teixeira ${ }^{1 *}$; Neusa Saltiel Stobbe ${ }^{2}$; Verônica Schmidt ${ }^{3}$; \\ Valéria Marçal Felix de Lima ${ }^{4}$; Ana Luisa Tartarotti ${ }^{5}$; Raquel Rocha Ramos ${ }^{6}$; \\ Flávio Antônio Pacheco de Araujo ${ }^{7}$
}

\begin{abstract}
Leishmaniosis are zoonoses that present several clinical manifestations in humans and have dogs as their main reservoir in the urban environment. Visceral leishmaniasis (VL) is the most severe form of the parasitosis and has been increasing in Brazil, despite the actions of public health agencies. Until 2002, the State of Rio Grande do Sul (RS) was considered free of human and canine leishmaniasis. The first human case of cutaneous leishmaniasis in RS was recorded in 2003. In 2009, the first autochthonous cases of human VL and canine visceral leishmaniasis (CVL) were confirmed in São Borja, RS, and the occurrence of the insect vector was recorded for the first time in the state. In 2010, the first confirmed case of CVL was reported and seropositive dogs were identified in the city of Porto Alegre, RS. Given the importance of this zoonosis and the difficulties of a reliable diagnosis in dogs, this study aimed to identify epidemiological aspects of CVL in dogs in an area of Porto Alegre where cases of the disease have been reported. A total of 300 blood samples were collected from dogs in this area, which were then tested by the methods of RT-DPP ${ }^{\circledR}$ and ELISA for diagnosis of Leishmania infantum. An epidemiological questionnaire was completed by dog owners, containing aspects related to care of the animals, characteristics of their environment, and their living conditions. We observed that $83 \%(250 / 300)$ of the studied dogs were of mixed breed, 58\% (175/300) were female, 78\% (238/300) slept outdoors, and 61\% (183/300) shared their living quarters with other species. Clinically, we observed that $90 \%(270 / 300)$ of the animals were infested by ectoparasites, $70 \%(210 / 300)$ had dermatopathies, $24 \%$ (72/300) presented weight loss and anorexia, and $22 \%(65 / 300)$ had ocular disorders. The results of the two serological tests were $100 \%$ concordant for the three seropositive samples (1\%), and the remaining 297 (99\%) were negative for both tests. We conclude that despite the low prevalence of $L$. infantum seropositive dogs, conditions in the region are favorable for CVL transmission, creating a risk of VL for the human population in the city of Porto Alegre. Key words: Visceral Leishmaniasis. Dogs. Serologic Diagnosis. Porto Alegre.
\end{abstract}

${ }^{1}$ Prof $^{\mathrm{a}}$ Dr $^{\mathrm{a}}$ Assistente I, Centro Universitário Ritter dos Reis, UniRitter, Brasil. E-mail: caetanoteixeira@gmail.com

2 Prof. Adjunto, Departamento de Microbiologia e Parasitologia, Instituto de Ciências Básicas da Saúde, Universidade Federal do Rio Grande do Sul, UFRGS, RS, Brasil. E-mail: neusa.stobbe@ufgrs.br

${ }^{3}$ Prof $^{a}$ Dr $^{\mathrm{a}}$ Adjunto, Departamento de Medicina Veterinária Preventiva, UFRGS, RS, Brasil. E-mail: veronica.schmidt@ufgrs.br

${ }^{4}$ Prof. Dr. Adjunto, Departamento de Clínica, Cirurgia e Reprodução Animal, Faculdade de Medicina Veterinária de Araçatuba, UNESP, Araçatuba, Brasil. E-mail: vmflima@fmva.unesp.br

${ }_{5}^{5}$ MédicaVeterinária, Divisão de Vigilância Ambiental em Saúde, Secretaria Estadual de Saúde do Rio Grande do Sul, CEVS, RS, Brasil. E-mail: altartarotti@yahoo.com.br

${ }^{6}$ Bióloga, Seção de Parasitologia, Laboratório Central do Estado (IPB-LACEN), Fundação Estadual de Produção e Pesquisa em Saúde- FEPPS, RS, Brasil. E-mail: raquel-ramos@fepps.rs.gov.br

7 Prof. Dr. de Protozoologia, Departamento de Patologia Veterinária, UFRGS, RS, Brasil. E-mail: faraujo@via-rs.net

* Author for correspondence 


\section{Resumo}

As leishmanioses são zoonoses que apresentam diversas manifestações clínicas no homem e tem o cão como seu principal reservatório no ambiente urbano. A Leishmaniose visceral (LV) é a forma mais grave da parasitose e sua ocorrência tem aumentado no Brasil, apesar das ações dos órgãos de saúde pública. Até o do ano de 2002, o Estado do Rio Grande do Sul era área indene para as leishmanioses humana e canina. Em 2003 foi registrado o primeiro caso humano da forma tegumentar. Em 2009, foram confirmados os primeiros casos autóctones humanos de LV e caninos de Leishmaniose visceral canina (LVC) no município de São Borja/RS e registrada, pela primeira vez, a ocorrência do inseto vetor no estado. Em 2010, foi notificado o primeiro caso confirmado de LVC e identificados cães sororreagentes em Porto Alegre/RS. Tendo em vista a importância desta zoonose e as dificuldades de um diagnóstico confiável em cães, o presente estudo objetivou identificar aspectos epidemiológicos da LVC em cães em uma região com registros de casos no município de Porto Alegre/RS. Coletaram-se 300 amostras de sangue de cães desta região as quais foram testas pelos métodos Dual Path Platform (TR-DPP ${ }^{\circledR}$ ) e ELISA para diagnóstico de Leishmania infantum. Um questionário epidemiológico foi aplicado durante entrevista com os tutores, contendo aspectos relativos à criação dos animais e fatores ambientais. Verificou-se que 83\% (250/300) dos cães não tinham raça definida, 58\% (175/300) eram fêmeas, 78\% (238/300) dormiam ao ar livre e 61\% (183/300) conviviam com outras espécies animais. Clinicamente, observou-se que 90\% (270/300) dos animais apresentavam infestação por ectoparasitos, 70\% (210/300) apresentavam alterações dermatológicas, 24\% (72/300) emagrecimento e anorexia e 22\% (65/300) alterações oculares. Os resultados dos testes sorológicos foram $100 \%$ concordantes uma vez que as mesmas três amostras (1\%) apresentaram reação positiva e as demais 297 (99\%) foram negativas em ambos os métodos diagnósticos. Concluiu-se que, apesar da baixa prevalência de cães soropositivos para L. infantum, existem condições de transmissão de LVC, com risco de LV para a população humana no município de Porto Alegre.

Palavras-chave: Leishmaniose Visceral. Cães. Diagnóstico Sorológico. Porto Alegre.

\section{Introduction}

Visceral leishmaniasis (VL), a zoonotic chronic disease caused by the protozoan Leishmania infantum, is of great importance in South America, especially in Brazil (DESJEUX, 2004). The first autochthonous case of canine visceral leishmaniasis (CVL) in the state of Rio Grande do Sul (RS) was recorded in 2008, and the vector Lutzomyia longipalpis was found in São Borja, RS, in that same year (BULLETIN EPIDEMIOLOGICAL, 2010). Subsequently, five human cases and one death were confirmed in São Borja (SOUZA et al., 2010). Dogs (Canis familiaris) are the main reservoir of $L$. infantum in the domestic environment (GONTIJO; MELO, 2004). In Porto Alegre, RS, the first confirmed case of canine visceral leishmaniasis (CVL) was recorded in 2010 in a dog living in a peri-urban area of the county.

Clinical manifestations of CVL in dogs include weight loss, onychogryphosis, and skin, visceral, and hematological alterations leading to death. Confirmed diagnosis can be achieved with parasitological, serologic, or molecular tests (BANETH, 2006; MARCONDES et al., 2011; VERAS et al., 2014). The TR-DPP® technique and the indirect enzyme-linked immunosorbent assay (ELISA) are the serologic tests recommended by the Ministry of Health in Brazil, to be applied in seroprevalence studies done with canine samples or surveyed census (BRASIL, 2008).

Strategies that can reduce the spread of canine leishmaniasis include strict control of dogs' movement, implementation of mandatory serological diagnosis, mandatory reporting of positive canine cases, and education of both dog owners and veterinarians working in public and private institutions (FIGUEIREDO et al., 2012) CVL serum epidemiological results from different regions of Brazil range from 1 to $65 \%$ (AZEVEDO et al., 2008; TASCA et al., 2009; ASSIS et al., 2010). These numbers vary with the region studied, 
diagnostic technique, and methodology applied. In the southern region, a seropositive rate of $1.37 \%$ was found in dogs in Florianópolis in the state of Santa Catarina (STEINDEL et al., 2013), where there were three cases of dogs with clinical symptoms compatible with CVL among the 2124 dogs tested (FIGUEIREDO et al., 2012). In the western region of RS, where the first cases of CVL in the state were identified, $20.8 \%$ of dogs tested by ELISA were seropositive (TARTAROTTI et al., 2011). In studies done in Porto Alegre, of 200 dogs that lived near confirmed human cases of cutaneous leishmaniasis and were tested, $3.5 \%$ were positive by indirect immunofluorescence (IFAT) (JESUS, 2006) and 30 (3.5\%) by ELISA (IESBICH, 2008); both studies used Leishmania spp. antigens. The aim of the present study was to investigate the prevalence of antibodies against $L$. infantum in dogs living in an area of Porto Alegre, RS, in which cases of CVL have occurred.

\section{Materials and Methods}

\section{Study area}

The city of Porto Alegre is the center of Brazil's fourth largest metropolitan area, having a population of 1,409,551 (IBGE, 2012) and an area of 470.25 $\mathrm{km}^{2}$. For this study we selected an area adjacent to the Avenida do Trabalhador that was $19 \mathrm{~km}$ long and had an estimated population of 150,000 inhabitants. The study area included the site of the first record in the city of dogs seropositive for Leishmania spp. and the site of the first record of an indigenous case of CVL (Figure 1).

Figure 1. Study area in the city of Porto Alegre in the state of Rio Grande do Sul, showing the area around the Avenida do Trabalhador: 1) Site of the first record in the city of dogs seropositive for Leishmania spp.; 2) Site of the first record of an autochthonous case of CVL.

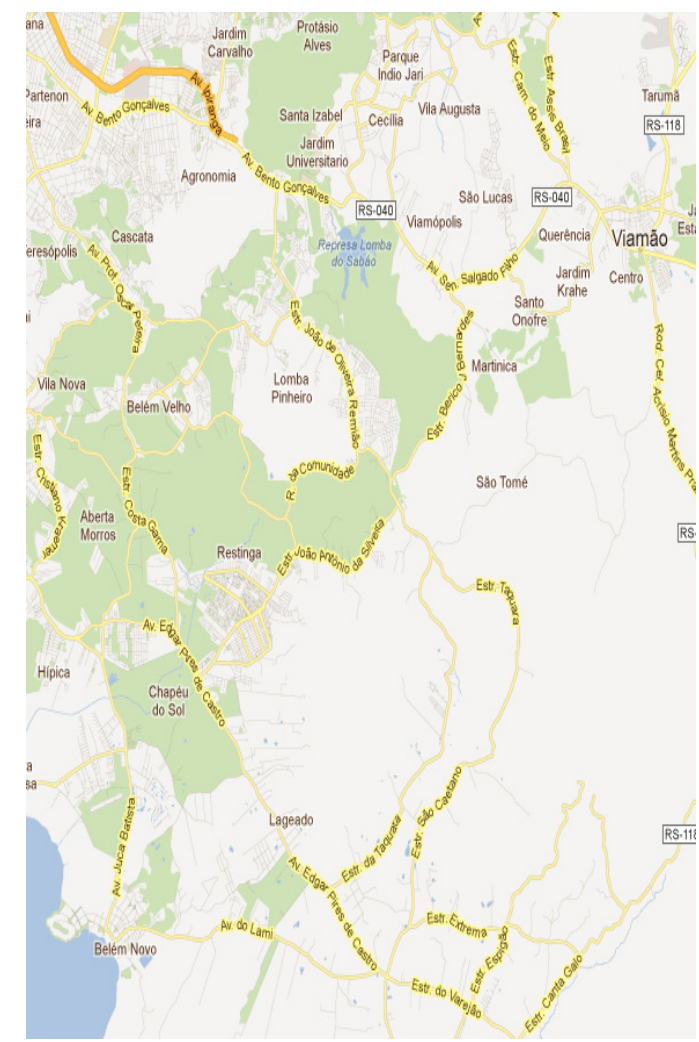

Source: http://www.googlemaps.com 


\section{Sampling}

We conducted a cross-sectional observational study to estimate CVL prevalence in dogs. We used non-probability sampling, and sample size calculation considered the following parameters: estimated prevalence and $95 \%$ confidence interval (CI), and a minimum sample of 200 dogs. Agreement by the dog owner to participate in the study was an inclusion factor. The total number of dogs tested was 300, and the period of sample collection was from September 2012 to September 2013. The samples were obtained by intravenous cannulation of the jugular vein and placed in tubes without anticoagulant. Each tube was individually identified and the material was centrifuged at 2200 rpm for 10 min to obtain serum and kept frozen at $20^{\circ} \mathrm{C}$ for further use.

\section{Methods}

The epidemiological profile of the canine population in the region was determined by a structured questionnaire that was given to dog owners at the time of blood collection. The questionnaire had closed- and open-ended questions that related to the dog's age, race, and sex. It also collected information on clinical evaluation of the animal and how it was cared for. Each home was also visited. All dog owners authorized the blood collection and signed a consent statement.

This study was approved by the Ethics Committee of the Federal University of Rio Grande do Sul (n. 21286).

The presence of antibodies against $L$. infantum was determined using the Dual Path Platform Rapid Test (TRDPP ${ }^{\circledR}$, Biomanguinhos) used according to the manufacturer's recommendations.

Indirect ELISA was performed according to the technique recommended by Lima et al. (2005), using total antigen of $L$. infantum lysate at a concentration of $20 \mu \mathrm{g} \mathrm{ml}^{-1}$ and rabbit immunoglobulin of dog anti-IgG-1 conjugated to peroxidase (Sigma ${ }^{\circledR}$,
USA). The samples were processed in duplicate with a cut-off optical density (OD) of 0.270 . The reading was performed in a spectrophotometer with a 490-nm filter.

\section{Statistical analysis}

The simple frequency of immune response was determined, and analyses were performed of the descriptive profiles of the studied dogs as well as other observations and responses from the questionnaire.

\section{Results}

The study area included urbanized areas with high population density interspersed with large areas of native forest and small farms. Great social vulnerability was observed, often in conjunction with poor waste disposal practices and poor sanitation in households combined with a large population of stray dogs.

A total of $83 \%(250 / 300)$ of the dogs were classified as of mixed breed, 58.3\% (175/300) were female, and their average age was 5.5 years, with a range of nine months to 16 years. The average number of dogs per household was six, with some owners having only one dog while others had 22. Regarding the life conditions of dogs, $78 \%$ (238/300) slept in kennels or in the backyard of their homes and $61 \%(183 / 300)$ coexisted with other animal species on the same property (such as chickens, horses, and cats).

Seventy-two percent of the owners (216/300) reported that their dogs did not receive routine veterinary care. According to the clinical evaluation, many dogs showed with signs compatible with CVL as follows: $70 \%(220 / 300)$ had skin problems such as alopecia and pruritus; 24\% (72/300) had progressive weight loss and lack of appetite; $22 \%(65 / 300)$ had ocular abnormalities, and 90\% $(270 / 300)$ were infested with ectoparasites. 
Of the 300 serum samples analyzed, three (1\%) were positive for both serology tests, with the positive ELISA tests showing optical densities of $1.322,0.630$, and 0.590 . The remaining samples were negative for both tests. The three seropositive dogs were from Lageado Quarter, lived on the same property, and spent the nights in the backyard of the house. These three dogs were a female Golden Retriever, a female Pitbull, and a male Pitbull, aged four, five, and seven years, respectively. Of the three positive animals, only the female Pitbull $(\mathrm{OD}=1.322)$ exhibited progressive weight loss. The property on which they lived was about $2 \mathrm{~km}$ from the site where first case of CVL was detected in the region and was a large area of green forest with the presence of horses, cats, and rodents. Compared to other homes visited during the study, the house where the seropositive dogs were kept was clean, had no accumulation of garbage or organic matter, and the dogs received frequent veterinary care.

\section{Discussion}

The environmental characteristics of the study area revealed serious problems with basic infrastructure and deficient sanitary conditions. Costa et al. (2005) evaluated the influence of basic services and sanitation in the city of Teresina in the state of Piauí, Brazil, and determined a higher risk of human infection in areas lacking proper sewage disposal and waste collection. These factors, according to Borges et al. (2014), can contribute to the occurrence of canine and human VL. The authors of a study in the city of Juatuba, Minas Gerais, Brazil, observed a disease prevalence of approximately $50 \%$ in neighborhoods with deficient sanitation and unpaved streets, characteristics that were also observed in the study area of our work. These results point to the existence of factors (deficient sanitation and unpaved streets) to be considered in the spread and occurrence of this disease.
The characteristics of the canine population and their living conditions match some of the factors associated with increased chances of infection in humans and dogs living in endemic areas of VL. One of these conditions is having the animal sleeping outdoors at night (COURA-VITAL et al., 2011). Nevertheless, this behavior does not seem to be a determining factor for infection, as most sampled animals slept outdoors.

A study done in the city of Cuiabá, Mato Grosso, Brazil (ALMEIDA et al., 2012), found that dogs sleeping outdoors and having free access to the street are important factors for infection with VL. According to these authors, rural dogs were 1.9 times more likely to contract the infection than were urban dogs. Although the three positive animals in the present study resided in an area that is considered urban, the environment around the house had characteristics similar to those of rural areas, including the presence of native forest areas and of other animals such as horses. These characteristics may favor the maintenance of sandfly populations.

Feitosa et al. (2000) reported that most positive animals were between three and six years old. This predisposition of adult dogs to have the disease can be explained by its long incubation period (SOARES; TURCO, 2003; SEIXAS et al., 2012). In the present study, the age of seropositive dogs ranged from four to seven years, within the age group most prone to the disease. However, Seixas et al. (2012) studied the risk factors for infection in an active transmission area of the protozoa in the state of Bahia, Brazil, and concluded that age and sex had no influence on the chance of being seropositive, whereas the animal's origin did influence seroconversion.

In the current study, the finding that many seronegative dogs had clinical signs considered compatible with CVL can be explained by the fact that the clinical signs of CVL are not pathognomonic. The great socio-economic needs of the region, the lack of veterinary care (as 
reported by dog owners), and the large number of dogs seen in some residences may contribute to the transmission and spread of other diseases and ectoparasites that produce clinical signs similar to those observed in CVL. However, it is important to note that some authors estimate that $50 \%$ to $60 \%$ of infected animals in endemic areas are asymptomatic (ALVAR et al., 2004; MACHADO et al., 2007). A detailed clinical evaluation followed by highly sensitive tests are effective for identifying dogs with CVL both in endemic and silent areas (VERAS et al., 2014).

The fact that we found only three samples positive for $L$. infantum in the present study does not allow a comparative assessment between the serological techniques used, although the results of both techniques were fully concordant.

The prevalence of seropositive animals observed in this study (1\%) is below that found in endemic areas in Brazil, but it is close to the $1.37 \%$ rate seen in the city of Florianópolis in Santa Catarina (STEINDEL et al., 2013). Importantly, Santa Catarina and Rio Grande do Sul were the last states where CVL canine cases were reported in Brazil, illustrating the expansion of CVL and highlighting the importance of the movement of animals in the region.

The detection of CVL in Porto Alegre, the capital of Rio Grande do Sul, is of great concern because the population is unaware of the spread of the disease into the region and that the dog population is exposed to the risk of infection. The lack of knowledge of the transmission dynamics in the area and of the presence of vector and wild reservoirs can contribute to sudden expansion of the disease, in contrast to what occurs in endemic regions (BORGES et al., 2014). The situation seen in Porto Alegre may also be occurring in other cities in Brazil, because road construction and increased air travel is increasing the traffic of people and their domestic animals, which, in turn, increases the risk of dispersion not only of CVL but other infectious diseases as well.

In the study region, the presence of $L$. longipalpis or Lutzomyia cruzi has not yet been reported, but entomological surveys are underway in the region, and there is a great need for more studies on the sandfly life cycle.

Although non-probability sampling may lack statistical rigor (MAROTTI et al., 2008), the present study identified CVL seropositive dogs in a nonendemic region, in which the first autochthonous case had only recently been identified (BULLETIN EPIDEMIOLOGICAL, 2010). The voluntary participation of 300 dog owners was important to this health survey, and such cooperation will be equally important for future epidemiological studies of the disease. Additionally, serological surveys of dog populations, such as the one we conducted here, can be of great value for control of the canine reservoir. Case identification in new areas may drive the direction of preventive actions in the region (BRASIL, 2006; BORGES et al., 2014.).

It is extremely important that entomological and epidemiological surveillance addressing CVL are implemented in unaffected areas in order to detect the presence of the vector and/or the canine enzootic before the anthropozoonotic cycle is established. These measures may permit the adoption of actions aimed at preventing the occurrence of the disease in humans, including preparation of the health services and education of the population.

\section{Conclusion}

The presence of dogs seropositive for Leishmania infantum in the city of Porto Alegre, Rio Grande do Sul, carries a potential risk to public health, as these animals live in environments that offer favorable conditions for the perpetuation of sandfly vectors. 


\section{References}

ALMEIDA, A. B. P. F.; SOUSA, V. R. F.; CRUZ, F. A. C. S.; DAHROUG, M. A. A.; FIGUEIREDO, F. B.; MADEIRA, M. F. Canine visceral leishmaniasis: seroprevalence and risk factors in Cuiabá, Mato Grosso, Brasil. Revista Brasileira de Parasitologia, Jaboticabal, v. 21, n. 4, p. 359-365, 2012.

ALVAR, J.; CANAVATE, C.; MOLINA, R.; MORENO, J.; NIETO, J. Canine Leishmaniasis. Advances in Parasitology, London, v. 57, n. 3, p. 1-88. 2004.

ASSIS, J.; QUEIROZ, N. M. G. P.; SILVEIRA, R. C.; NUNES, C. M.; OLIVEIRA, T. M. F. S.; NORONHA JUNIOR, A. C. F.; NEVES, M. F.; MACHADO, R. Z.; BUZETTI, W. A. S. Estudo comparativo dos métodos diagnósticos para Leishmaniose Visceral em cães oriundos de Ilha Solteira, SP. Revista Brasileira de Parasitologia Veterinária, Jaboticabal, v. 19, n. 1, p. 1725, 2010.

AZEVEDO, M. A. A.; DIAS, A. K. K.; PAULA, H. B. de; PERRI, S. H. V.; NUNES, C. M. Avaliação da Leishmaniose visceral canina em Poxoréo, Estado do Mato Grosso, Brasil. Revista Brasileira de Parasitologia Veterinária, Jaboticabal, v. 17, n. 3. p. 123-127, 2008.

BANETH, G. Leishmaniases. In: GREENE, C. E. Infections diseases. $3^{\text {th }}$ ed. [S.1.]: Elsevier, 2006. p. 686689.

BULLETIN EPIDEMIOLOGICAL /RS - Centro Estadual de Vigilância em Saúde. [S.1.: s,n.], 2010. ano XII, n. 44.

BORGES, L. F. N. M.; LOPES, E. G. P.; FREITAS, A. C. P.; SILVA, M. X.; HADDAD, J. P. A.; SILVA, J. A.; NICOLINO, R. R.; SOARES, D. F. M. Prevalencia e distribuição espacial da leishmaniose visceral em cães do município de Juatuba, Minas Gerais, Brasil. Ciência Rural, Santa Maria, v. 44, n. 2, p. 352-357, 2014.

BRASIL. Ministério da Saúde. Fundação Nacional de Saúde. Manual de vigilância e controle da leishmaniose visceral. Brasília: Ministério da Saúde, 2006. 137 p.

Ministério da Saúde e Ministério da Agricultura, Pecuária e Abastecimento. Portaria Interministerial $\mathrm{n}^{\mathrm{o}} 1426$, de 11 de julho de 2008. Proíbe o tratamento de leishmaniose visceral canina com produto de uso humano ou não registrado no Ministério da Agricultura, pecuária e Abastecimento. Diário Oficial [da] União, Brasília, Seção 1, p. 37. Disponível em: <http://www.dive.sc.gov.br/conteudos/ zoonoses/legislacao/portaria-1426-DOU11-07-08. pdf>. Acesso em: 12 abr. 2016.
COSTA, C. H. N.; WERNWCK, G.; RODRIGUES, L.; SANTOS, M. V.; ARAUJO, I. B.; MOURA, L. S.; MOREIRA, S.; GOMES, R. B.; LIMA, S. S. Household structures and urban services: neglected targets in the controlo f visceral leishmaniosis. Annais of Tropical Medicine and Parasitoly, v. 99, n. 3, p. 229-236, 2005.

COURA-VITAL, W.; MARQUES, M. J.; VELOSO, V. M.; ROATT, B. M.; AGUIAR-SOARES, R. D. O.; REIS, L. E. S.; BRAGA, S. L.; MORAES, M. H. F.; REIS, A. B.; CARNEIRO, M. Prevalence and factors associated with Leishmania infantum infecrion of dogs fron urban área of Brazil as identified by molecular methods. Plos Neglected Tropical Diseases, v. 5, n. 8, e1291, 2011.

DESJEUX, P. Leishmaniasis: current situation and new perspectives. Comparative Immunology Microbiology \&.Infections Diseaes, v. 27, n. 5, p. 305-318, 2004.

FEITOSA, M. M.; IKEDA, F. A.; LUVIZOTTO, M. C. R.; PERRI, S. H. V. Aspectos clínicos de cães com leishmaniose visceral no município de Araçatuba - São Paulo (Brasil). Clínica Veterinária, São Paulo, v. 5, n. 28, p. 36-44, 2000.

FIGUEIREDO, F. B.; LIMA JUNIOR, F. E. F. J.; TOMIO, E.; INDÁ, F. M. C.; CORREA, G. L. B.; MADEIRA, M. F. Leishmaniose Visceral Canina: dois casos autóctones no município de Florianópolis, estado de Santa Catarina. Acta Scientia Veterinaria, Porto Alegre, v. 40, n. 1, p. 1-4, 2012.

GOOGLEMAPS. Disponível em: <http://www. googlemaps.com>. Acesso em: 13 mar. 2012.

GONTIJO, C. M. F.; MELO, M. N. Leishmaniose visceral no Brasil. Revista Brasileira de Epidemiologia, São Paulo, v. 7, n. 3, p. 338-349, 2004.

IESBICH, M. M. P. Avaliação de amostras de soro canino para Leishmaniose Tegumentar Americana (LTA), em áreas de baixa endemicidade/Porto Alegre/RS através de métodos diagnósticos laboratoriais imunológicos $e$ biomoleculares. 2008. Dissertação (Mestrado em Ciências Veterinárias) - Universidade Federal do Rio Grande do Sul, Porto Alegre.

INSTITUITO BRASILEITO DE GEOGRAFIA E ESTATÍSTICA - IBGE Censo/2012. Disponível em: $<$ http://www.ibge.gov.br/home/estatistica/populacao/ estimativa2012/>. Acesso: 26 mar. 2013.

JESUS, J. R. Avaliação sorológica de anticorpos para Leishmania spp. através da reação de Imunoflurescência Indireta em população canina da região da Lomba do Pinheiro, cidade de Porto Alegre, RS, Brasil, a partir de casos autóctones humanos de Leishmaniose Tegumentar. 2006. Dissertação (Mestrado em Ciências Veterinárias) Universidade Federal do Rio Grande do Sul, Porto Alegre. 
LIMA, V. M. F.; BIAZZOMO, L.; SILVA, A. C.; CORREA, A. P. F. L.; LUVIZOTTO, M. C. R. Serological diagnosis of visceral leismaniasis by na enzyme immunoassay using protein A in naturally infected dogs. Pesquisa Veterinária Brasileira, Seropédica, v. 4, n. 4, p. 215-218, 2005.

MACHADO, J. G.; MORAES, J. R. C. M.; COSTA, R. T.; NASCIMENTO, E.; MOREIRA, E. C. Comparação dos resultados dos métodos de imunofluorescência indireta e ELISA indireto no diagnóstico sorológico da Leishmaniose visceral realizada pelos laboratórios de Belo Horizonte, MG, Brasil. Veterinária e Zootecnia, Botucatu, v. 14, n. 1, p. 47-51, 2007.

MARCONDES, M.; BIONDO, A. W.; GOMES, A. A. D.; SILVA, A. R. S.; VIEIRA, R. F. C.; CAMACHO, A. A.; QUINNG, J.; CHANDRASHEKARG, R. Validationof Leishmania infantum ELISA rapid test for serological diagnosis of Leishmania chagasi in dogs. Veterinary Parasitology, Amsterdam, v. 175, n. 1, p. 15-19, 2011.

MAROTTI, J.; GALAHARDO, A. P. M.; FURUYAMA, R. J.; PIGOZZO, M. N.; CAMPOS, T. N.; LAGANÁ, D. C. Amostragem em pesquisa clínica: tamanho da amostra. Revista de Odontologia da USP, São Paulo, v. 20, n. 2, p. 186-194, 2008.

SEIXAS, M. M.; MAGALHÃES JUNIOR, J. T.; FRANKE, C. R.; BARROUIN-MELO, S. M. Positividade para Leishmaniose visceral canina: existem fatores caninos que contribuem? Revista Baiana de Saúde Pública, Salvador, v. 36, n. 2, p. 358-367, 2012.

SOARES, R. P. P.; TURCO, S. J. Lutzomya longipalpis (Diptera:Psycodidae:Phlebotominae): a review. Anais da Academia Brasileira de Ciências, Rio de Janeiro v. 75, n. 3, p. 301-330, 2003.
SOUZA, N. P.; ALMEIRA, A. B. P. F.; FREITAS, T. P. T.; PAZ, R. C. R.; DUTRA, V.; NAKAZATO, L.; SOUSA, V. R. Leishmania (L) infantum chagasi em canídeos silvestres mantidos em cativeiro, no estado de Mato Grosso. Revista da Sociedade Brasileira de Medicina Tropical, Uberaba, v. 43, n. 3, p. 333-335, 2010.

STEINDEL, M.; MENIN, A.; EVANGELISTA, T.; STOCO, P. H.; MARLOW, M. A.; FLEITH, R. C.; PILATI, C.; GRISARD, E. C. Outbreak of autochthonous canine visceral leishmaniasis in Santa Catarina, Brazil. Pesquisa Veterinária Brasileira, Seropédica, v. 33, n. 4, p. 490-496, 2013.

TARTAROTTI, A. L.; DONINI, M. A.; ANJOS, C.; RAMOS, R. R. Vigilância de reservatórios caninos. Boletim Epidemiológico, Porto Alegre, v. 13, n. 1, p. 3-6, 2011.

TASCA, K. I.; BUZETTI, W. A. S.; TENORIO, M. S.; PAULAN, S. C.; LIMA, F. L.; QUEIROZ, N. M. G. P. Exames parasitológicos, imunoistoquimicos e histopatológicos para detecção de Leishmania chagasi em tecidos esplênicos de cães com leishmaniose visceral. Revista Brasileira de Parasitologia Veterinária, Jaboticabal, v. 18, n. 1, p. 27-33, 2009.

VERAS, P. S. T.; FRAGA, D. B. M.; SALCÀ, M. S.; GUEDES, C. E. S. New advances in the diagnosis of canine visceral Leismaniasis. Leishmaniasis. In: CLABORN, D. M. Trends in epidemiology, diagnosis and treatment. Rijeka, Croatia: InTech, 2014. Available at: <http://www.intechopen.com/books/leishmaniasistrends-in-epidemiology-diagnosis-and-treatment/ new-advances-in-the-diagnosis-of-canine-visceralleishmaniasis>. Accessed at: 20 mar. 2014. 